Article

\title{
One Single Nucleotide Polymorphism of the TRPM2 Channel Gene Identified as a Risk Factor in Bipolar Disorder Associates With Autism Spectrum Disorder in a Japanese Population
}

\author{
Naila Al Mahmuda ${ }^{1,2}{ }^{(0)}$, Shigeru Yokoyama ${ }^{1}$, Toshio Munesue ${ }^{1}$, Kenshi Hayashi ${ }^{3}{ }^{(0)}$, \\ Kunimasa Yagi ${ }^{3}$, Chiharu Tsuji ${ }^{1}$ and Haruhiro Higashida ${ }^{1,4, *(\mathbb{B}}$ \\ 1 Department of Basic Research on Social Recognition and Memory, Research Center for Child Mental \\ Development, Kanazawa University, Kanazawa 920-8640, Japan; nlmahmuda@gmail.com (N.A.M.); \\ shigeruy@med.kanazawa-u.ac.jp (S.Y.); munesue@med.kanazawa-u.ac.jp (T.M.); \\ ctsuji@med.kanazawa-u.ac.jp (C.T.) \\ 2 Faculty of Business Administration, Eastern University, Dhaka 1205, Bangladesh \\ 3 Division of Cardiovascular Medicine, Graduate School of Medical Science, Kanazawa University, \\ Kanazawa 920-8641, Japan; kenshi@med.kanazawa-u.ac.jp (K.H.); yagikuni@icloud.com (K.Y.) \\ 4 Laboratory for Social Brain Studies, Research Institute of Molecular Medicine and Pathobiochemistry, \\ Department of Biochemistry, Krasnoyarsk State Medical University named after Prof. V. F. Voino-Yasentsky, \\ Krasnoyarsk 660022, Russia \\ * Correspondence: haruhiro@med.kanazawa-u.ac.jp
}

Received: 15 November 2019; Accepted: 5 February 2020; Published: 7 February 2020

\begin{abstract}
The transient receptor potential melastatin 2 (TRPM2) is a non-specific cation channel, resulting in $\mathrm{Ca}^{2+}$ influx at warm temperatures from $34^{\circ} \mathrm{C}$ to $47^{\circ} \mathrm{C}$, thus including the body temperature range in mammals. TRPM2 channels are activated by $\beta-\mathrm{NAD}^{+}$, ADP-ribose (ADPR), cyclic ADPR, and $2^{\prime}$-deoxyadenosine $5^{\prime}$-diphosphoribose. It has been shown that TRPM2 cation channels and CD38, a type II or type III transmembrane protein with ADP-ribosyl cyclase activity, simultaneously play a role in heat-sensitive and $\mathrm{NAD}^{+}$metabolite-dependent intracellular free $\mathrm{Ca}^{2+}$ concentration increases in hypothalamic oxytocinergic neurons. Subsequently, oxytocin (OT) is released to the brain. Impairment of OT release may induce social amnesia, one of the core symptoms of autism spectrum disorder (ASD). The risk of single nucleotide polymorphisms (SNPs) and variants of TRPM2 have been reported in bipolar disorder, but not in ASD. Therefore, it is reasonable to examine whether SNPs or haplotypes in TRPM2 are associated with ASD. Here, we report a case-control study with 147 ASD patients and 150 unselected volunteers at Kanazawa University Hospital in Japan. The sequence-specific primer-polymerase chain reaction method together with fluorescence correlation spectroscopy was applied. Of 14 SNPs examined, one SNP (rs933151) displayed a significant $p$-value $(\mathrm{OR}=0.1798,95 \% \mathrm{CI}=0.039,0.83$; Fisher's exact test; $p=0.0196)$. The present research data suggest that rs93315, identified as a risk factor for bipolar disorder, is a possible association factor for ASD.
\end{abstract}

Keywords: SNP; ASD; bipolar disorder; TRPM2; CD38

\section{Introduction}

Autism spectrum disorder (ASD) is a pervasive neurodevelopmental disease [1-3]. Although the etiology accounting for ASD is not totally clear [1,4], it is now understood that such neurodisorders are the result of a multitude of factors, including environmental factors and genetic susceptibility $[5,6]$. Many studies have led to the identification of candidate genes whose variants and single nucleotide 
polymorphisms (SNPs) might be associated with ASD [7,8]. A recent genetic analysis suggested that common and rare variants contribute to ASD by perturbation of wide neuronal, proteomic, and genetic networks [9-11]. Because of the high heritability, the majority of research on ASD has been focused on finding underlying genetic risks, with less emphasis on possible environmental factors [12].

The core symptom of ASD is social impairment with communication problems [13]. Many studies have suggested that oxytocin (OT), a hormone with nine amino acids, plays a critical role in social behavior in mammals and humans [14-22]. A single administration of OT was revealed to have beneficial effects on social and emotional processes or impairments in both healthy subjects and individuals with a variety of psychiatric diseases, including ASD [23-28]. More practically, repetitive administrations of OT into the nasal cavity of individuals with ASD results in the reduction of social behavioral impairment and increased episodes of social interaction in daily life [29-56]. To support OT accumulation in the brain after peripheral application, it has recently been reported that the receptor for advanced glycation end products (RAGE) recruits OT from the blood circulation crossing over the blood-brain barrier, because RAGE is an OT-binding partner and carrier [57,58].

OT is released into the brain and is essential for social behavioral actions $[15,18,22,24,28,59-61]$. Recent studies revealed that more OT is released in a hypothalamus culture isolated from subordinate mice in group-housed males than from dominant mice, especially after cage-switch stress [62]. Upon stimulation with cyclic ADP-ribose (cADPR) through push-pull canulae, OT concentrations in micro-perfusates at the paraventricular nucleus were higher in subordinate mice compared with ordinate mice. The OT concentration of cerebrospinal fluid (CSF) was enhanced in endotoxin-shock mice with fever in comparison to controls without hyperthermia [62,63]. In mice exposed to the new environmental stress, the CSF OT level transiently increased 5 min after the start of exposure, during which the rectal temperature also increased. OT release under such conditions was sensitive to mRNA levels of the transient receptor potential melastatin 2 (TRPM2, previously known as TRPC7 or LTRPC2TRPM2) in the hypothalamus and to a TRPM2 antagonist [62]. Because TRPM2 cation channels are warm-sensitive channels $[64,65]$, the above findings indicate that hyperthermia regulates hypothalamic OT secretion during social stress by intracellular free $\mathrm{Ca}^{2+}$ concentration elevation resulting from TRPM2-dependent $\mathrm{Ca}^{2+}$ influx and CD38-controled $\mathrm{Ca}^{2+}$ mobilization.

Therefore, it is rational to consider that the TRPM2 gene may contribute to the etiology of ASD and that the TRPM2 channel is a potential therapeutic target in social impairments in ASD with respect to OT release. Interestingly, abnormal functions of TRPM2 have been reported to be risk factors in bipolar disorder, although there are no genetic studies on TRPM2 for ASD [66]. To assess this, we screened 14 SNPs in the TRPM2 gene and verified the association of SNPs of TRPM2 with ASD in the same Japanese population, in which genetic variants and/or SNPs of CD38, BST1/CD157, and SLC19A1 were reported as risk factors of ASD $[29,67,68]$. Finally, we will discuss pathophysiological roles of TRPM2 channels in the brain and neurological diseases.

\section{Experimental Section}

\subsection{Subjects/Children with ASD and Healthy Controls}

There were 147 ASD subjects, including 113 males and 34 females (mean age: $15.6 \pm 0.6$ years) from the psychiatry and child mental clinics of Kanazawa University Hospital [29,68]. All patients satisfied the Diagnostic and Statistical Manual of Mental Disorders (DSM)-IV criteria for pervasive developmental disorder. Such subjects were diagnosed by psychiatrists through interviews and observations of their behaviors in the playroom [29]. They had no history of noticeable physical abnormalities. The diagnosis of ASD for all participants was independently confirmed by an experienced child psychiatrist by semi-structured behavior observations as well as through interviews with the patients and their mothers and/or fathers. In the process of evaluating ASD during interviews, the examiner used one of the following methods: the Asperger Syndrome Diagnostic Interview, the Autism Diagnostic Interview-Revised, the Pervasive Developmental Disorders Autism Society 
Japan Rating Scale, the Diagnostic Interview for Social and Communication Disorders, or the Tokyo Autistic Behavior Scale [46]. We excluded two ASD subjects due to a lack of results in the SNP analysis.

As the control group, 115 male and 35 female volunteers (mean age: $23.8 \pm 0.3$ years) who had no history of physical or mental disorders were accounted. However, four control subjects were excluded due to insufficient results in the SNP analysis. All participants were Japanese, with Japanese parents and grandparents. This study was approved by the ethics committees of Kanazawa University School of Medicine. All examinations were performed after informed consent was obtained from the parents or guardians of all children in accordance with the Declaration of Helsinki.

\subsection{Genotyping}

Genomic DNA was extracted as previously described [69] from venous blood samples using a kit (Wizard Genomic DNA Purification kit; Promega, Madison, WI, USA), or from nails using the ISOHAIR DNA extraction kit (Nippon Gene, Tokyo, Japan). In some cases, the whole genome amplification method (the REPLI-g kit; Qiagen, Hilden, Germany) was applied in order to increase DNA concentrations. The genotypes of each SNP were determined at Kurabo Industries Ltd. (Osaka, Japan) by the sequence-specific primer (SSP)-PCR method, which was combined with fluorescence correlation spectroscopy [70]. We picked up tagging SNPs that cover common variations. Linkage disequilibrium (LD) structures over the TRPM2 gene were analyzed by the Tagger program equipped with the Haploview v4.2 software (Broad Institute of MIT and Harvard, Cambridge, MA, USA). We used the dbSNP database for tagging SNPs [71]: the HapMap genome browser, release 27 (the National Institutes of Health, Bethesda, MD, USA), the JPT (Japanese individuals from Tokyo, Japan), CHB (Han Chinese individuals from Beijing, China), ASW (African ancestry in Southwest USA), and CEU (Utah residents of northern and western European ancestry). The selection of tagging SNPs was based on pairwise tagging. The minor allele frequency $\geq 5 \%$ was selected in any one of the different ethnicities.

\subsection{Statistical Analysis}

A contingency table and Fisher's exact test (GraphPad Prism 6; GraphPad Software, San Diego, CA, USA) were used to examine genotypes and allele frequencies. In this study, $p<0.05$ was taken to indicate statistical significance. The genotype frequency distributions calculated were compared with those expected from the Hardy-Weinberg equilibrium. The chi " $\chi$ " squared test was applied. Statistical power was processed using the Genetic Power Calculator [72-75]. Calculations were performed by estimating a population prevalence of 0.015 for ASD [74] and a $D^{\prime}$ value of 1 between the marker and disease, with a false positive rate of $5 \%$.

\section{Results}

In this study, 16 SNPs of TRPM2 on human chromosome 21, whose physical locations are shown in Figure 1, were subjected to analysis in case-control association samples of the initial samples of 145 cases and 146 controls. First, two SNPs (rs3788122 and rs9982220) were excluded because of insufficient genotyping data. In 13 SNPs, an association with ASD was not found. One SNP, rs933151, provided evidence for an association. rs933151 was significant, with the empirical $p$-value of 0.0196 (Table 1). However, rs933151 did not show evidence of an association, with $\chi^{2}=1.940$ $(p=0.3791)$. This indicates that rs933151 alone or in combination with others is a weak risk factor for ASD. Interestingly, it has been reported that rs933151 is associated with bipolar disorder [76]. This SNP was further analyzed. 


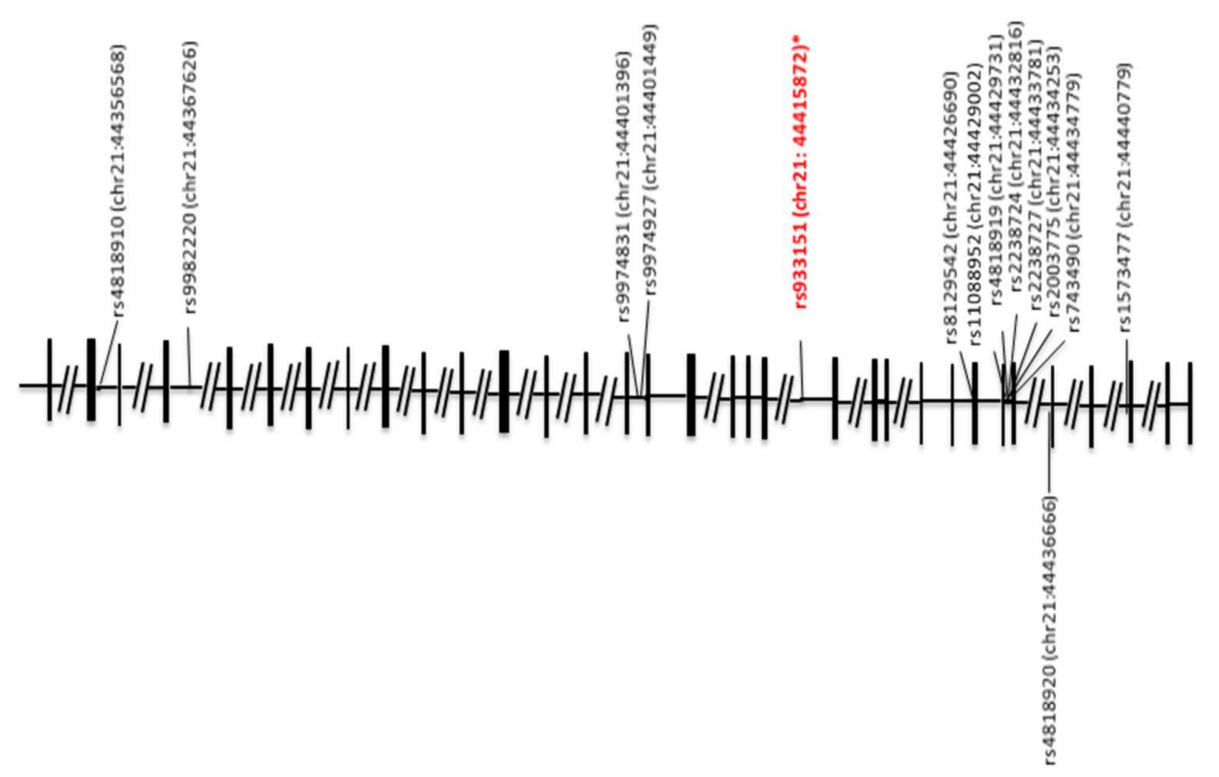

Figure 1. Schematic genomic structure of the human TRPM2 gene and locations of single nucleotide polymorphisms (SNPs). The exon-intron organization is depicted based on GenBank accession numbers NC_000021. The SNP (red and italicized) represents a significant association with ASD in allele and/or genotype frequencies in the present study; the asterisk indicates a previously reported bipolar disorder association [76]. The locations of the SNPs on human chromosome 21 (chr21) are indicated in parentheses; numbers after colons represent genomic positions based on the human genome assembly GRCh38/hg19 at the University of California Santa Cruz (UCSC) Genome Bioinformatics Site.

Table 1. Genotype and allele frequencies of rs933151 in control and ASD subjects.

\begin{tabular}{ccccc}
\hline & Cases & Controls & Odds Ratio & $\boldsymbol{P}$ \\
\hline Genotype & $(n=145)$ & $(n=146)$ & $\mathbf{( 9 5 \% ~ C I ) ~}$ & \\
A/A & $88(60.7 \%)$ & $89(61.0 \%)$ & Referent & \\
A/G & $46(31.7 \%)$ & $55(38.2 \%)$ & $1.182(0.72,1.93)$ & 0.5341 \\
G/G & $11(7.6 \%)$ & $2(1.2 \%)$ & $0.1798(\mathbf{0 . 0 3 9}, 0.83)$ & $\mathbf{0 . 0 1 9 6}$ \\
Allele & $(n=290)$ & $(n=292)$ & & \\
A & $222(76.6 \%)$ & $233(79.8 \%)$ & Referent & \\
G & $68(23.4 \%)$ & $59(20.2 \%)$ & $0.8267(0.56,1.23)$ & 0.3672 \\
\hline
\end{tabular}

CI: confidence interval. $p$-values obtained by the Fisher exact test for genotype and by Chi-square test for allele are given. Bold means significance.

Tests of Hardy-Weinberg equilibrium deviations were performed for each marker in case and control individuals. Polymorphisms showed evidence of deviation from the Hardy-Weinberg equilibrium. The genotyping rate was above $95 \%$. LD analysis of these SNPs identified three haplotype blocks, one of which (Block 1; Figure 2) consisted of three SNPs, including the one (rs933151) with the lowest $p$-value among those analyzed: Statistic $\chi^{2}=4.550(p=0.1028)$. 


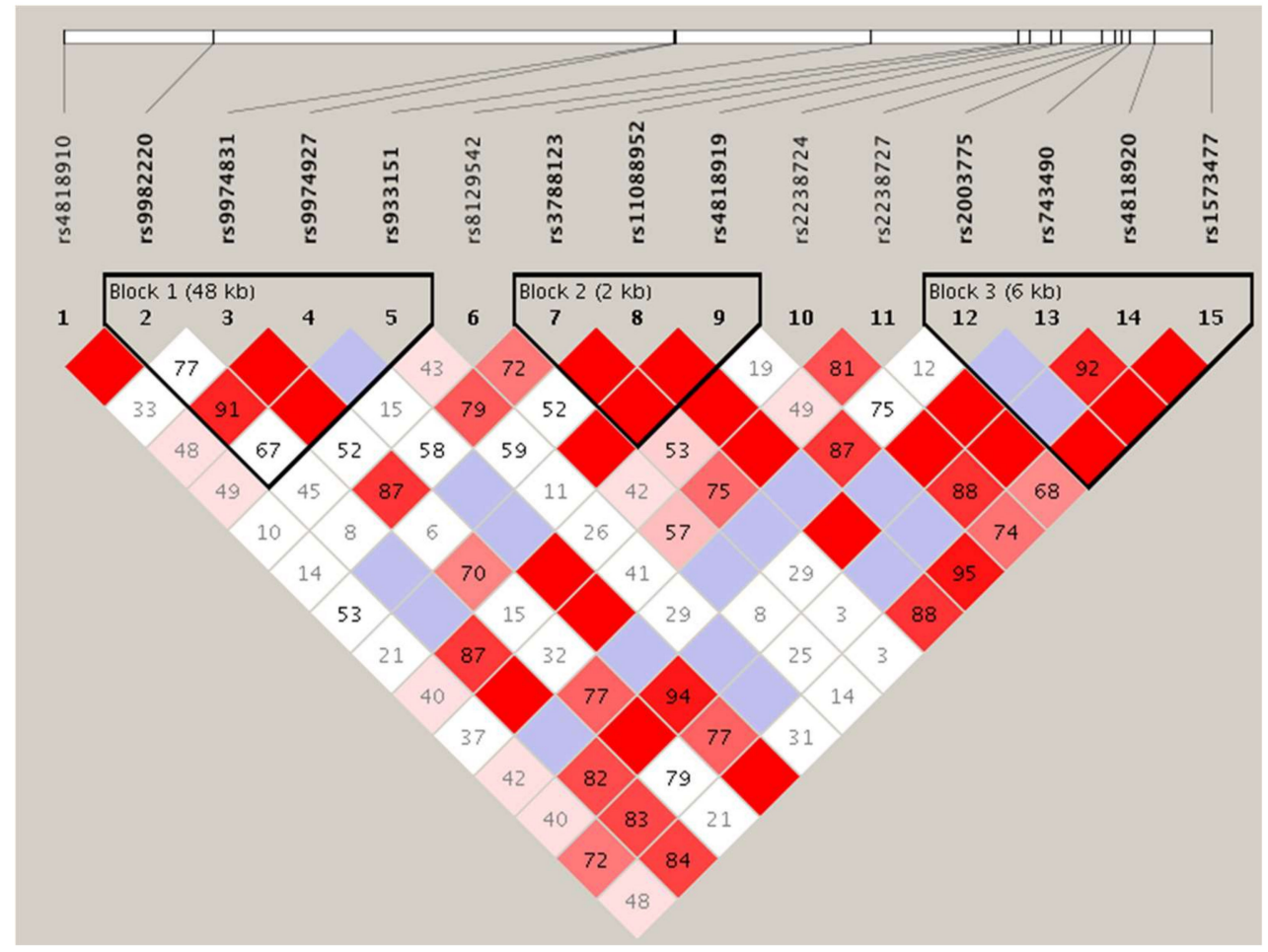

Figure 2. Linkage disequilibrium plot of SNPs of TRPM2 in the samples examined. Numbers in squares indicate $D^{\prime}$ values. The blocks are defined following the four-gamete rule [75] Explanation of color scheme: If $D^{\prime}<1$ and LOD ( $\log$ of the likelihood odds ratio) $<2$, the cell color is white; if $D^{\prime}=1$ and $\mathrm{LOD}<2$, it is blue; if $D^{\prime}<1$ and LOD $\geq 2$, shades of pink/red; if $D^{\prime}=1$ and $\mathrm{LOD} \geq 2$, bright red.

Hardy-Weinberg analysis showed a significant frequency variation in the A/A, A/G, and G/G genotypes of rs933151 of TRPM2 in 145 cases and 146 controls (Supplementary Table 1). The frequency of the A/A, A/G, and G/G genotypes was $0.64,0.32$, and 0.04 in the control subjects, respectively, and $0.59,0.36$, and 0.05 in ASD subjects, respectively. Chi square $\left(\chi^{2}\right)$ goodness-of-fit test values for the controls and ASD subjects were $4.13(p=0.0421)$ and $1.94(p=0.1637)$, respectively. In the $\mathrm{A} / \mathrm{A}$ and $\mathrm{A} / \mathrm{G}$ genotypes, allele frequency was found to be significant at the 0.05 level. Furthermore, the Elston-Forthofer average test revealed A $=445$ and 212 for the control and ASD subjects, respectively, confirming the significant differences in the allele frequency of rs933151.

\section{Discussion}

Specific SNPs or variants associated with multiple neuronal disorders and cross-disorder phenotypes have been identified [77]. The major finding of this study is the weak association of ASD with the SNP rs933151 in intron 20 of TRPM2 (Figure 1) [76,78-80]. Similarly, with respect to TRPM2, it has been reported that the SNP rs1556314 in exon 11 was associated with bipolar disorder type I in the Caucasian case control dataset and in the family design. In addition, the C-T-A haplotype of SNPs rs1618355, rs933151, and rs749909 of the TRPM2 gene was significantly associated with early age at onset in bipolar disorder type I families [76]. An association between ASD or attention-deficit hyperactivity disorder and TRPM2 has not been reported yet [81]. Thus, the current article reveals for the first time that rs933151 may be related to both ASD and bipolar disorder. This finding regarding rs933151 seems to be particularly meaningful in the psychiatric field, because ASD sometimes occurs concurrently with bipolar disease [1]. However, we should keep in mind that the insensitivity of this study design of population stratification creates a factor that can lead to false association [82].

In relation to hyperthermia involving TRPM2 channels, a beneficial effect of fever in ASD patients has been reported [62]. Some ASD children exhibit improvements in their behavioral characteristics during febrile incidents [62,63,83-87]. Febrigenesis and behavioral changes induced by fever in 
ASD may depend on the facilitation of brain OT release or the normalization of the impaired locus coeruleus-noradrenergic system [87].

Zhong et al. [62] and Higashida et al. [63] reported the new neuroendocrinological evidence for involvement of the warm temperature-sensor cation channel TRPM2 in OT release. They showed that incubation with cADPR induced minor but sustained increases in the OT concentration in the culture medium of the hypothalamus. However, the OT concentration markedly increased (by approximately 4 -fold) with simultaneous heat stimulation from $35^{\circ} \mathrm{C}$ to $38.5^{\circ} \mathrm{C}$ compared with the pre-stimulation level [62]. The mechanism for enhanced OT release is owing to increased cellular $\mathrm{Ca}^{2+}$ concentrations. It is speculated that cADPR activates $\mathrm{Ca}^{2+}$ mobilization from ryanodine-sensitive $\mathrm{Ca}^{2+}$ pools [15] and enhances $\mathrm{Ca}^{2+}$ influx by TRPM2 channels [62], because cADPR binds to the NUDT9-H domain of TRPM2 channels for opening [88]. Of course, heat gates TRPM2 $\mathrm{Ca}^{2+}$ channels.

The same mechanism by TRPM2 would be expected in ASD patients. Hyperthermia may induce temporal remission, probably because of the increased release of OT in the brain in ASD subjects. Thus, investigating how the SNP rs933151 and phosphorylated glycogen synthase kinase-3 [66,89] may influence this TRPM2-sensitive OT release is the next step we have to take.

Recently, the physiological functions of TRPM2 in the brain have been identified [66,90]. TRPM2 resides not only in neurons, but also astrocytes or microglial cells, which play a role in cognitive functions [91-94]. The mRNA expression profile in microglia of TRPM2 in the hypothalamus and striatum of the developing rat brain has been shown to be paralleled with the perinatal expression timeline for microglial infiltration and maturation [95]. TRPM2 has been shown to be involved in embryonic neurogenesis [96]. Moreover, aberrant TRPM2 function seems to be associated with psychiatric and neurological diseases, such as stress-induced depression [97], epilepsy [94], ischemic brain injury [98-100], and glioma invasion [99]. Therefore, it is possible that TRPM2 mutants and TRPM2 expression during neuronal development may contribute in the pathogenesis of ASD [1,3,7,96] and bipolar disorder [66,89-91,96,101].

\section{Conclusions}

Although limitations in the small size of the current cohort are clear, we reported a weak association between ASD and the SNP (rs933151) of the TRPM2 gene in a Japanese population. The rs933151 SNP has already been reported as a risk factor in bipolar disorder. Our results necessitate further analysis of TRPM2 SNPs in ASD patients on a large scale. It remains unclear whether the variants causing the amino acid mutation of TRPM2 found in bipolar disorder patients $[66,76,80,89]$ are also risk factors in ASD.

Supplementary Materials: The following are available online at http://www.mdpi.com/2079-9721/8/1/4/s1, Table S1: Statistics for cases and controls.

Author Contributions: H.H. and N.A.M conceived and designed the research. N.A.M. and S.Y. performed experiments and analyzed data. T.M., K.H., and K.Y. contributed to participant recruitment, clinical assessment, and sample collection. N.A.M. prepared the initial draft and N.A.M. and H.H. revised the manuscript. All authors have read and agreed to the published version of the manuscript.

Funding: This work was funded by the industry-academia collaborative R\&D programs (COI) and by Collaborative Research Network for Asian Children with Developmental Disorders from the Ministry of Education, Culture, Sports, Science and Technology of Japan.

Conflicts of Interest: The authors declare no competing interests.

\section{References}

1. Lai, M.C.; Lombardo, M.V.; Baron-Cohen, S. Autism. Lancet 2014, 383, 896-910. [CrossRef]

2. Elsabbagh, M.; Divan, G.; Koh, Y.J.; Kim, Y.S.; Kauchali, S.; Marcín, C.; Montiel-Nava, C.; Patel, V.; Paula, C.S.; Wang, C.; et al. Global prevalence of autism and other pervasive developmental disorders. Autism Res. 2012, 5, 160-179. [CrossRef] [PubMed] 
3. Richards, C.; Jones, C.; Groves, L.; Moss, J.; Oliver, C. Prevalence of autism spectrum disorder phenomenology in genetic disorders: A systematic review and meta-analysis. Lancet Psychiatry 2015, 2, 909-916. [CrossRef]

4. Sullivan, P.F.; Geschwind, D.H. Defining the Genetic, Genomic, Cellular, and Diagnostic Architectures of Psychiatric Disorders. Cell 2019, 177, 162-183. [CrossRef]

5. Vijayakumar, N.T.; Judy, M.V. Autism spectrum disorders: Integration of the genome, transcriptome and the environment. J. Neurol. Sci. 2016, 364, 167-176. [CrossRef]

6. Modabbernia, A.; Velthorst, E.; Reichenberg, A. Environmental risk factors for autism: An evidence-based review of systematic reviews and meta-analyses. Mol. Autism 2017, 8, 13. [CrossRef]

7. Grove, J.; Ripke, S.; Als, T.D.; Mattheisen, M.; Walters, R.K.; Won, H.; Pallesen, J.; Agerbo, E.; Andreassen, O.A.; Anney, R.; et al. Identification of common genetic risk variants for autism spectrum disorder. Nat. Genet. 2019, 51, 431-444. [CrossRef]

8. Bourgeron, T. Current knowledge on the genetics of autism and propositions for future research. C. R. Biol. 2016, 339, 300-307. [CrossRef]

9. Ben-David, E.; Shifman, S. Networks of neuronal genes affected by common and rare variants in autism spectrum disorders. PLoS Genet. 2012, 8, e1002556. [CrossRef]

10. Katayama, Y.; Nishiyama, M.; Shoji, H.; Ohkawa, Y.; Kawamura, A.; Sato, T.; Suyama, M.; Takumi, T.; Miyakawa, T.; Nakayama, K.I. CHD8 haploinsufficiency results in autistic-like phenotypes in mice. Nature 2016, 537, 675-679. [CrossRef]

11. Parras, A.; Anta, H.; Santos-Galindo, M.; Swarup, V.; Elorza, A.; Nieto-González, J.L.; Picó, S.; Hernández, I.H.; Díaz-Hernández, J.I.; Belloc, E.; et al. Autism-like phenotype and risk gene mRNA deadenylation by CPEB4 mis-splicing. Nature 2018, 560, 441-446. [CrossRef] [PubMed]

12. Gandal, M.J.; Zhang, P.; Hadjimichael, E.; Walker, R.L.; Chen, C.; Liu, S.; Won, H.; van Bakel, H.; Varghese, M.; Wang, Y.; et al. Transcriptome-wide isoform-level dysregulation in ASD, schizophrenia, and bipolar disorder. Science 2018, 362, eaat8127. [CrossRef] [PubMed]

13. Swedo, S.E.; American Psychiatric Association. Autism Spectrum Disorder. In Diagnostic and Statistical Manual of Mental Disorders (DSM-5), 5th Ed. ed; American Psychiatric Association: Washington, DC, USA, 2013; pp. 50-59.

14. Pedersen, C.A.; Prange, A.J., Jr. Induction of maternal behavior in virgin rats after intracerebroventricular administration of oxytocin. Proc. Natl. Acad. Sci. USA 1979, 76, 6661-6665. [CrossRef]

15. Jin, D.; Liu, H.X.; Hirai, H.; Torashima, T.; Nagai, T.; Lopatina, O.; Shnayder, N.A.; Yamada, K.; Noda, M.; Seike, T.; et al. CD38 is critical for social behaviour by regulating oxytocin secretion. Nature 2007, 446, 41-45. [CrossRef] [PubMed]

16. Goodson, J.L.; Thompson, R.R. Nonapeptide mechanisms of social cognition, behavior and species-specific social systems. Curr. Opin. Neurobiol. 2010, 20, 784-794. [CrossRef] [PubMed]

17. Johnson, Z.V.; Young, L.J. Evolutionary diversity as a catalyst for biological discovery. Integr. Zool. 2018, 13, 616-633. [CrossRef]

18. Insel, T.R. The challenge of translation in social neuroscience: A review of oxytocin, vasopressin, and affiliative behavior. Neuron 2010, 65, 768-779. [CrossRef]

19. Torres, N.; Martins, D.; Santos, A.J.; Prata, D.; Veríssimo, M. How do hypothalamic nonapeptides shape youth's sociality? A systematic review on oxytocin, vasopressin and human socio-emotional development. Neurosci. Biobehav. Rev. 2018, 90, 309-331. [CrossRef]

20. Grinevich, V.; Desarménien, M.G.; Chini, B.; Tauber, M.; Muscatelli, F. Ontogenesis of oxytocin pathways in the mammalian brain: Late maturation and psychosocial disorders. Front. Neuroanat. 2015, 8, 164. [CrossRef]

21. Bartz, J.A.; Zaki, J.; Bolger, N.; Ochsner, K.N. Social effects of oxytocin in humans: Context and person matter. Trends Cogn. Sci. 2011, 15, 301-309. [CrossRef]

22. Chini, B.; Leonzino, M.; Braida, D.; Sala, M. Learning About Oxytocin: Pharmacologic and Behavioral Issues. Biol. Psychiatry 2014, 76, 360-366. [CrossRef] [PubMed]

23. Yamasue, H.; Domes, G. Oxytocin and Autism Spectrum Disorders. Curr. Top. Behav. Neurosci. 2017, 35, 449-465.

24. Feldman, R. The Neurobiology of Human Attachments. Trends Cogn. Sci. 2017, 21, 80-99. [CrossRef] [PubMed] 
25. Francis, S.M.; Sagar, A.; Levin-Decanini, T.; Liu, W.; Carter, C.S.; Jacob, S. Oxytocin and vasopressin systems in genetic syndromes and neurodevelopmental disorders. Brain Res. 2014, 1580, 199-218. [CrossRef] [PubMed]

26. Modahl, C.; Green, L.; Fein, D.; Morris, M.; Waterhouse, L.; Feinstein, C.; Levin, H. Plasma oxytocin levels in autistic children. Biol. Psychiatry 1998, 43, 270-277. [CrossRef]

27. Green, L.; Fein, D.; Modahl, C.; Feinstein, C.; Waterhouse, L.; Morris, M. Oxytocin and autistic disorder: Alterations in peptide forms. Biol. Psychiatry 2001, 50, 609-613. [CrossRef]

28. Neumann, I.D.; Slattery, D.A. Oxytocin in General Anxiety and Social Fear: A Translational Approach. Biol. Psychiatry 2016, 79, 213-221. [CrossRef]

29. Munesue, T.; Yokoyama, S.; Nakamura, K.; Anitha, A.; Yamada, K.; Hayashi, K.; Asaka, T.; Liu, H.X.; Jin, D.; Koizumi, K.; et al. Two genetic vriants of CD338 in subjects with autism spectrum disorder and controls. Neurosci. Res. 2010, 67, 181-191. [CrossRef]

30. Okamoto, Y.; Ishitobi, M.; Wada, Y.; Kosaka, H. The Potential of Nasal Oxytocin Administration for Remediation of Autism Spectrum Disorders. CNS Neurol. Disord. Drug Targets 2016, 15, 564-577. [CrossRef]

31. Hollander, E.; Novotny, S.; Hanratty, M.; Yaffe, R.; DeCaria, C.M.; Aronowitz, B.R.; Mosovich, S. Oxytocin infusion reduces repetitive behaviors in adults with autistic and Asperger's disorders. Neuropsychopharmacology 2003, 28, 193-198. [CrossRef]

32. Hollander, E.; Bartz, J.; Chaplin, W.; Phillips, A.; Sumner, J.; Soorya, L.; Anagnostou, E.; Wasserman, S. Oxytocin increases retention of social cognition in autism. Biol. Psychiatry 2007, 61, 498-503. [CrossRef] [PubMed]

33. Guastella, A.J.; Einfeld, S.L.; Gray, K.M.; Rinehart, N.J.; Tonge, B.J.; Lambert, T.J.; Hickie, I.B. Intranasal oxytocin improves emotion recognition for youth with autism spectrum disorders. Biol. Psychiatry 2010, 67, 692-694. [CrossRef] [PubMed]

34. Andari, E.; Duhamel, J.R.; Zalla, T.; Herbrecht, E.; Leboyer, M.; Sirigu, A. Promoting social behavior with oxytocin in high-functioning autism spectrum disorders. Proc. Natl. Acad. Sci. USA 2010, 107, 4389-4394. [CrossRef] [PubMed]

35. Bakermans-Kranenburg, M.J.; van Ijzendoorn, M.H. Sniffing around oxytocin: Review and meta-analyses of trials in healthy and clinical groups with implications for pharmacotherapy. Transl. Psychiatry 2013, 3, e258. [CrossRef]

36. Domes, G.; Heinrichs, M.; Kumbier, E.; Grossmann, A.; Hauenstein, K.; Herpertz, S.C. Effects of intranasal oxytocin on the neural basis of face processing in autism spectrum disorder. Biol. Psychiatry 2013, 74, 164-171. [CrossRef]

37. Watanabe, T.; Abe, O.; Kuwabara, H.; Yahata, N.; Takano, Y.; Iwashiro, N.; Natsubori, T.; Aoki, Y.; Takao, H.; Kawakubo, Y. Mitigation of socio communicational deficits of autism through oxytocin-induced recovery of medial prefrontal activity: A randomized trial. JAMA Psychiatry 2014, 71, 166-175. [CrossRef]

38. Domes, G.; Kumbier, E.; Heinrichs, M.; Herpertz, S.C. Oxytocin promotes facial emotion recognition and amygdala reactivity in adults with Asperger syndrome. Neuropsychopharmacology 2014, 39, 698-706. [CrossRef]

39. Alvares, G.A.; Quintan, D.S.; Whitehouse, A.J. Beyond the hype and hope: Critical considerations for intranasal oxytocin research in autism spectrum disorder. Autism Res. 2017, 10, 25-41. [CrossRef]

40. DeMayo, M.M.; Song, Y.J.C.; Hickie, I.B.; Guastella, A.J. A Review of the Safety, Efficacy and Mechanisms of Delivery of Nasal Oxytocin in Children: Therapeutic Potential for Autism and Prader-Willi Syndrome, and Recommendations for Future Research. Paediatr. Drugs 2017, 19, 391-410. [CrossRef]

41. Yamasue, H. Promising evidence and remaining issues regarding the clinical application of oxytocin in autismspectrum disorders. Psychiatry Clin. Neurosci. 2016, 70, 89-99. [CrossRef]

42. Guastella, A.J.; Hickie, I.B. Oxytocin Treatment, Circuitry, and Autism: A Critical Review of the Literature Placing Oxytocin into the Autism Context. Biol. Psychiatry 2016, 79, 234-242. [CrossRef] [PubMed]

43. Aoki, Y.; Watanabe, T.; Abe, O.; Kuwabara, H.; Yahata, N.; Takano, Y.; Iwashiro, N.; Natsubori, T.; Takao, H.; Kawakubo, Y. Oxytocin's neurochemical effects in the medial prefrontal cortex underlie recovery of task-specific brain activity in autism: A randomized controlled trial. Mol. Psychiatry 2015, 20, 447-453. [CrossRef] [PubMed]

44. Auyeung, B.; Lombardo, M.V.; Heinrichs, M.; Chakrabarti, B.; Sule, A.; Deakin, J.B. Oxytocin increases eye contact during a real-time, naturalistic social interaction in males with and without autism. Transl. Psychiatry 2015, 5, e507. [CrossRef] [PubMed] 
45. Quintana, D.S.; Westlye, L.T.; Hope, S.; Nærland, T.; Elvsåshagen, T.; Dørum, E.; Rustan, Ø.; Valstad, M.; Rezvaya, L.; Lishaugen, H.; et al. Dose-dependent social-cognitive effects of intranasal oxytocin delivered with novel Breath Powered device in adults with autism spectrum disorder: A randomized placebo-controlled double-blind crossover trial. Transl. Psychiatry 2017, 7, e1136. [CrossRef] [PubMed]

46. Munesue, T.; Nakamura, H.; Kikuchi, M.; Miura, Y.; Takeuchi, N.; Anme, T.; Nanba, E.; Adachi, K.; Tsubouchi, K.; Sai, Y. Oxytocin for Male Subjects with Autism Spectrum Disorder and Comorbid Intellectual Disabilities: A Randomized Pilot Study. Front. Psychiatry 2016, 7, 2. [CrossRef] [PubMed]

47. Kosaka, H.; Munesue, T.; Ishitobi, M.; Asano, M.; Omori, M.; Sato, M.; Anme, T.; Orisaka, M.; Ishitobi, M.; Jung, M.; et al. Long-term oxytocin administration improves social behaviors in a girl with autistic disorder. BMC Psychiatry 2012, 12, 110. [CrossRef] [PubMed]

48. Yamasue, H.; Okada, T.; Munesue, T.; Kuroda, M.; Fujioka, T.; Uno, Y.; Matsumoto, K.; Kuwabara, H.; Mori, D.; Okamoto, Y.; et al. Effect of intranasal oxytocin on the core social symptoms of autism spectrum disorder: A randomized clinical trial. Mol. Psychiatry 2018, 1-10. [CrossRef]

49. Anagnostou, E.; Soorya, L.; Chaplin, W.; Bartz, J.; Halpern, D.; Wasserman, S.; Wang, A.T.; Pepa, L.; Tanel, N.; Kushki, A.; et al. Intranasal oxytocin versus placebo in the treatment of adults with autism spectrum disorders: A randomized controlled trial. Mol. Autism 2012, 3, 16. [CrossRef]

50. Dadds, M.R.; MacDonald, E.; Cauchi, A.; Williams, K.; Levy, F.; Brennan, J. Nasal oxytocin for social deficits in childhood autism: A randomized controlled trial. J. Autism. Dev. Disord. 2014, 44, 521-531. [CrossRef]

51. Guastella, A.J.; Gray, K.M.; Rinehart, N.J.; Alvares, G.A.; Tonge, B.J.; Hickie, I.B.; Keating, C.M.; Cacciotti-Saija, C.; Einfeld, S.L. The effects of a course of intranasal oxytocin on social behaviors in youth diagnosed with autism spectrum disorders: A randomized controlled trial. J. Child Psychol. Psychiatry 2015, 56, 444-452. [CrossRef]

52. Benner, S.; Aoki, Y.; Watanabe, T.; Endo, N.; Abe, O.; Kuroda, M.; Kuwabara, H.; Kawakubo, Y.; Takao, H.; Kunimatsu, A.; et al. Neurochemical evidence for differential effects of acute and repeated oxytocin administration. Mol. Psychiatry 2018, 1-11. [CrossRef]

53. Yatawara, C.J.; Einfeld, S.L.; Hickie, I.B.; Davenport, T.A.; Guastella, A.J. The effect of oxytocin nasal spray on social interaction deficits observed in young children with autism: A randomized clinical crossover trial. Mol. Psychiatry 2016, 21, 1225-1231. [CrossRef] [PubMed]

54. Parker, K.J.; Oztan, O.; Libove, R.A.; Sumiyoshi, R.D.; Jackson, L.P.; Karhson, D.S.; Summers, J.E.; Hinman, K.E.; Motonaga, K.S.; Phillips, J.M.; et al. Intranasal oxytocin treatment for social deficits and biomarkers of response in children with autism. Proc. Natl. Acad. Sci. USA 2017, 114, 8119-8124. [CrossRef] [PubMed]

55. Owada, K.; Okada, T.; Munesu, T.; Kuroda, M.; Fujioka, T.; Uno, Y.; Matsumoto, K.; Kuwabara, H.; Mori, D.; Okamoto, Y.; et al. Quantitative facial expression analysis revealed the efficacy and time course of oxytocin in autism. Brain 2019, 142, 2127-2136. [CrossRef] [PubMed]

56. Higashida, H.; Munesue, T.; Kosaka, H.; Yamasue, H.; Yokoyama, S.; Kikuchi, M. Social Interaction Improved by Oxytocin in the Subclass of Autism with Comorbid Intellectual Disabilities. Diseases 2019, 7, E24. [CrossRef]

57. Yamamoto, Y.; Liang, M.; Munesue, S.; Deguchi, K.; Harashima, A.; Furuhara, K.; Yuhi, T.; Zhong, J.; Akther, S.; Goto, H.; et al. Vascular RAGE transports oxytocin into the brain to elicit its maternal bonding behaviour in mice. Commun. Biol. 2019, 2, 1-13. [CrossRef]

58. Higashida, H.; Furuhara, K.; Yamauchi, A.M.; Deguchi, K.; Harashima, A.; Munesue, S.; Lopatina, O.; Gerasimenko, M.; Salmina, A.B.; Zhang, J.S.; et al. Intestinal transepithelial permeability of oxytocin into the blood is dependent on the receptor for advanced glycation end products in mice. Sci. Rep. 2017, 7, 1-15. [CrossRef]

59. Higashida, H. Somato-axodendritic release of oxytocin into the brain due to calcium amplification is essential for social memory. J. Physiol. Sci. 2016, 66, 275-282. [CrossRef]

60. Johnson, Z.V.; Young, L.J. Oxytocin and vasopressin neural networks: Implications for social behavioral diversity and translational neuroscience. Neurosci. Biobehav. Rev. 2017, 76, 87-98. [CrossRef]

61. Neumann, I.D.; Landgraf, R. Tracking oxytocin functions in the rodent brain during the last 30 years: From push-pull perfusion to chemogeneticsilencing. J. Neuroendocrinol. 2019, 31, e12695. [CrossRef] 
62. Zhong, J.; Amina, S.; Liang, M.; Akther, S.; Yuhi, T.; Nishimura, T.; Tsuji, C.; Tsuji, T.; Liu, H.X.; Hashii, M.; et al. Cyclic ADP-ribose and heat regulate oxytocin release via CD38 and TRPM2 in the hypothalamus during social or psychological stress in mice. Front. Neurosci. 2016, 10, 304. [CrossRef]

63. Higashida, H.; Yuhi, T.; Akther, S.; Amina, S.; Zhong, J.; Liang, M.; Nishimura, T.; Liu, H.X.; Lopatina, O. Oxytocin release via activation of TRPM2 and CD38 in the hypothalamus during hyperthermia in mice: Implication for autism spectrum disorder. Neurochem. Int. 2018, 119, 42-48. [CrossRef] [PubMed]

64. Kashio, M.; Tominaga, M. The TRPM2 channel: A thermo-sensitive metabolic sensor. Channels 2017, 11, 426-433. [CrossRef]

65. Liu, H.X.; Lopatina, O.; Amina, S.; Higashida, C.; Islam, M.I.; Graeff, R.; Lee, H.L.; Hashii, M.; Higashida, H. Intracellular Calcium Concentrations Regulated by Cyclic ADP-Ribose and Heat in the Mouse Hypothalamus. Messenger 2012, 1, 150-159. [CrossRef]

66. Belrose, J.C.; Jackson, M.F. TRPM2: A candidate therapeutic target for treating neurological diseases. Acta Pharmacol. Sin. 2018, 39, 722-732. [CrossRef] [PubMed]

67. Yokoyama, S.; Al Mahmuda, N.; Munesue, T.; Hayashi, K.; Yagi, K.; Yamagishi, M.; Higashida, H. Association Study between the CD157/BST1 Gene and Autism Spectrum Disorders in a Japanese Population. Brain Sci. 2015, 5, 188-200. [CrossRef]

68. Mahmuda, N.A.; Yokoyama, S.; Huang, J.J.; Liu, L.; Munesue, T.; Nakatani, H.; Hayashi, K.; Yagi, K.; Yamagishi, M.; Higashida, H. A Study of Single Nucleotide Polymorphisms of the SLC19A1/RFC1 Gene in Subjects with Autism Spectrum Disorder. Int. J. Mol. Sci. 2016, 17, e772. [CrossRef]

69. Ma, W.J.; Hashii, M.; Munesue, T.; Hayashi, K.; Yagi, K.; Yamagishi, M.; Higashida, H.; Yokoyama, S. Non-synonymous single-nucleotide variations of the human oxytocin receptor gene and autism spectrum disorders: A case-control study in a Japanese population and functional analysis. Mol. Autism 2013, 4, 22. [CrossRef]

70. Nishida, N.; Tanabe, T.; Takasu, M.; Suyama, A.; Tokunaga, K. Further development of multiplex single nucleotide polymorphism typing method, the DigiTag2 assay. Anal. Biochem. 2007, 364, 78-85. [CrossRef]

71. dbSNP: Short Genetic Variations. Available online: http://www.ncbi.nlm.nih.gov/SNP/ (accessed on 24 June 2015).

72. Purcell, S.; Cherny, S.S.; Sham, P.C. Genetic power calculator: Design of linkage and association genetic mapping studies of complex traits. Bioinformatics 2003, 19, 149-150. [CrossRef]

73. Genetic Power Calculator. Available online: http://pngu.mgh.harvard.edu/purcell/gpc/cc2.html (accessed on 27 June 2015).

74. Developmental Disabilities Monitoring Network Surveillance Year 2010 Principal Investigators; Centers for Disease Control and Prevention (CDC). Prevalence of autism spectrum disorder among children aged 8 years-Autism and developmental disabilities monitoring network, 11 sites, USA, 2010. MMWR Surveill. Summ. 2014, 63, 1-21.

75. Wang, N.; Akey, J.M.; Zhang, K.; Chakraborty, R.; Jin, L. Distribution of recombination crossovers and the origin of haplotype blocks: The interplay of population history, recombination, and mutation. Am. J. Hum. Genet. 2002, 71, 1227-1234. [CrossRef] [PubMed]

76. Xu, C.; Li, P.P.; Cooke, R.G.; Parikh, S.V.; Wang, K.; Kennedy, J.L.; Warsh, J.J. TRPM2 variants and bipolar disorder risk: Confirmation in a family-based association study. Bipolar Disord. 2009, 11, 1-10. [CrossRef] [PubMed]

77. Cross-Disorder Group of the Psychiatric Genomics Consortium et al. Identification of risk loci with shared effects on five major psychiatric disorders: A genome-wide analysis. Lancet 2013, 381, 1371-1379. [CrossRef]

78. Nagamine, K.; Kudoh, J.; Minoshima, S.; Kawasaki, K.; Asakawa, S.; Ito, F.; Shimizu, N. Molecular cloning of a novel putative $\mathrm{Ca}^{2+}$ channel protein (TRPC7) highly expressed in brain. Genomics 1998, 54, 124-131. [CrossRef] [PubMed]

79. Uemura, T.; Kudoh, J.; Noda, S.; Kanba, S.; Shimizu, N. Characterization of human and mouse TRPM2 genes: Identification of a novel $\mathrm{N}$-terminal truncated protein specifically expressed in human striatum. Bichem. Biophys. Res. Commun. 2005, 328, 1232-1243. [CrossRef] [PubMed] 
80. McQuillin, A.; Bass, N.J.; Kalsi, G.; Lawrence, J.; Puri, V.; Choudhury, K.; Detera-Wadleigh, S.D.; Curtis, D.; Gurling, H.M. Fine mapping of a susceptibility locus for bipolar and genetically related unipolar affective disorders, to a region containing the C21ORF29 and TRPM2 genes on chromosome 21q22.3. Mol. Psychiatry 2006, 11, 134-142. [CrossRef]

81. Kim, D.S.; Burt, A.A.; Ranchalis, J.E.; Wilmot, B.; Smith, J.D.; Patterson, K.E.; Coe, B.P.; Li, Y.K.; Bamshad, M.J.; Nikolas, M.; et al. Sequencing of sporadic Attention-Deficit Hyperactivity Disorder (ADHD) identifies novel and potentially pathogenic de novo variants and excludes overlap with genes associated with autism spectrum disorder. Am. J. Med. Genet. B Neuropsychiatr. Genet. 2017, 174, 381-389. [CrossRef]

82. Ioannidis, J.P.; Ntzani, E.E.; Trikalinos, T.A.; Contopoulos-Ioannidis, D.G. Replication validity of genetic association studies. Nat. Genet. 2001, 29, 244-245. [CrossRef]

83. Good, P. Do salt cravings in children with autistic disorders reveal low blood sodium depleting brain taurine and glutamine? Med. Hypotheses 2011, 77, 1015-1021. [CrossRef]

84. Curran, L.K.; Newschaffer, C.J.; Lee, L.C.; Crawford, S.O.; Johnston, M.V.; Zimmerman, A.W. Behaviors associated with fever in children with autism spectrum disorders. Pediatrics 2007, 120, e1386-e1392. [CrossRef]

85. Naviaux, J.C.; Wang, L.; Li, K.; Bright, A.T.; Alaynick, W.A.; Williams, K.R.; Powell, S.B.; Naviaux, R.K. Antipurinergic therapy corrects the autism-like features in the Fragile X (Fmr1 knockout) mouse model. Mol. Autism 2015, 6, 1.

86. Naviaux, R.K.; Curtis, B.; Li, K.; Naviaux, J.C.; Bright, A.T.; Reiner, G.E.; Westerfield, M.; Goh, S.; Alaynick, W.A.; Wang, L.; et al. Low-dose suramin in autism spectrum disorder: A small, phase I/II, randomized clinical trial. Ann. Clin. Transl. Neurol. 2017, 4, 491-505. [CrossRef] [PubMed]

87. Mehler, M.F.; Purpura, D.P. Autism, fever, epigenetics and the locus coeruleus. Brain Res. Rev. 2009, 59, 388-392. [CrossRef] [PubMed]

88. Huang, Y.; Winkler, P.A.; Sun, W.; Lü, W.; Du, J. Architecture of the TRPM2 channel and its activation mechanism by ADP-ribose and calcium. Nature 2018, 562, 145-149. [CrossRef]

89. Jang, Y.; Lee, S.H.; Lee, B.; Jung, S.; Khalid, A.; Uchida, K.; Tominaga, M.; Jeon, D.; Oh, U. TRPM2, a Susceptibility Gene for Bipolar Disorder, Regulates Glycogen Synthase Kinase-3 Activity in the Brain. J. Neurosci. 2015, 35, 11811-11823. [CrossRef]

90. Sita, G.; Hrelia, P.; Graziosi, A.; Ravegnini, G.; Morroni, F. TRPM2 in the Brain: Role in Health and Disease. Cells 2018, 7, e82. [CrossRef]

91. Kakae, M.; Miyanohara, J.; Morishima, M.; Nagayasu, K.; Mori, Y.; Shirakawa, H.; Kaneko, S. Pathophysiological Role of TRPM2 in Age-Related Cognitive Impairment in Mice. Neuroscience 2019, 408, 204-213. [CrossRef]

92. Malko, P.; Syed Mortadza, S.A.; McWilliam, J.; Jiang, L.H. TRPM2 Channel in Microglia as a New Player in Neuroinflammation Associated with a Spectrum of Central Nervous System Pathologies. Front. Pharmacol. 2019, 10, 239. [CrossRef]

93. Turlova, E.; Feng, Z.P.; Sun, H.S. The role of TRPM2 channels in neurons, glial cells and the blood-brain barrier in cerebral ischemia and hypoxia. Acta Pharmacol. Sin. 2018, 39, 713-721. [CrossRef]

94. Zheng, Q.; Zhu, T.; Hu, H.; Zhao, Y.; Ying, Y.; Luo, X.; Ling, Y.; Chen, Z.; Ji, H.; Jiang, P. TRPM2 ion channel is involved in the aggravation of cognitive impairment and down regulation of epilepsy threshold in pentylenetetrazole-induced kindling mice. Brain Res. Bull. 2020, 155, 48-60. [CrossRef]

95. Ratnam, M.; Chan, J.; Lesani, N.; Sidorova-Darmos, E.; Eubanks, J.H.; Aarts, M.M. mRNA expression of transient receptor potential melastatin (TRPM) channels 2 and 7 in perinatal brain development. Int. J. Dev. Neurosci. 2018, 69, 23-31. [CrossRef] [PubMed]

96. Li, Y.; Jiao, J. Deficiency of TRPM2 leads to embryonic neurogenesis defects in hyperthermia. Sci. Adv. 2020, 6, eaay6350. [CrossRef] [PubMed]

97. Ko, S.Y.; Wang, S.E.; Lee, H.K.; Jo, S.; Han, J.; Lee, S.H.; Choi, M.; Jo, H.R.; Seo, J.Y.; Jung, S.J.; et al. Transient receptor potential melastatin 2 governs stress-induced depressive-like behaviors. Proc. Natl. Acad. Sci. USA. 2019, 116, 1770-1775. [CrossRef] [PubMed]

98. Huang, S.; Turlova, E.; Li, F.; Bao, M.H.; Szeto, V.; Wong, R.; Abussaud, A.; Wang, H.; Zhu, S.; Gao, X. Transient receptor potential melastatin 2 channels (TRPM2) mediate neonatal hypoxic-ischemic brain injury in mice. Exp. Neurol. 2017, 296, 32-40. [CrossRef] 
99. Bao, M.H.; Lv, Q.L.; Szeto, V.; Wong, R.; Zhu, S.Z.; Zhang, Y.Y.; Feng, Z.P.; Sun, H.S. TRPM2-AS inhibits the growth, migration, and invasion of gliomas through JNK, c-Jun, and RGS4. J. Cell. Physiol. 2019, 2019, 1-11. [CrossRef]

100. Akpınar, H.; Nazıroğlu, M.; Övey, İ.S.; Çiğ, B.; Akpınar, O. The neuroprotective action of dexmedetomidine on apoptosis, calcium entry and oxidative stress in cerebral ischemia-induced rats: Contribution of TRPM2 and TRPV1 channels. Sci. Rep. 2018, 6, 37196. [CrossRef]

101. Sanches, M. The Limits between Bipolar Disorder and Borderline Personality Disorder: A Review of the Evidence. Diseases 2019, 7, e49. [CrossRef]

(C) 2020 by the authors. Licensee MDPI, Basel, Switzerland. This article is an open access article distributed under the terms and conditions of the Creative Commons Attribution (CC BY) license (http://creativecommons.org/licenses/by/4.0/). 